\title{
Madness and Folly and the Extraordinary Reason of Love in Romeo and Juliet
}

\section{Sybil Truchet}

\section{(2) OpenEdition}

1 Journals

\section{Electronic version}

URL: http://journals.openedition.org/shakespeare/1308

DOI: 10.4000/shakespeare.1308

ISSN: 2271-6424

\section{Publisher}

Société Française Shakespeare

Printed version

Date of publication: 1 November 1989

Number of pages: 17-26

\section{Electronic reference}

Sybil Truchet, "Madness and Folly and the Extraordinary Reason of Love in Romeo and Juliet », Actes des congrès de la Société française Shakespeare [Online], 7| 1989, Online since 01 January 2007,

connection on 04 May 2019. URL : http://journals.openedition.org/shakespeare/1308 ; DOI : 10.4000/ shakespeare. 1308 


\title{
Société Française Shakespeare
}

\author{
Actes des Congrès \\ 1985 - 1986 - 1987
}

\section{LA FOLIE}

\section{SHAKESPEARE ET LES ARTS \\ LE TRAGIQUE}




\section{MADNESS AND FOLLY \\ AND THE EXTRAORDINARY REASON OF LOVE IN $\ll R O M E O$ AND JULIET»}

Sybil TRUCHET

In the opening stages of the play Shakespeare's viewpoint of reason and folly is an orthodox one. He starts by judging the traditional folly of the lover through the comic antics of Romeo. The audience is invited to laugh as Romeo, the frustrated, melancholy lover, disrupts the normal law of life, wandering about at night for example, but remaining cloistered in a darkened bedroom during the day. Showing the symptoms that Robert Burton will make famous later on ${ }^{1}$, Romeo flounders helplessly in the throes of his infatuation, blind to all but the object of his yearning :

Not mad, but bound more than a madman is :

Shut up in prison, kept without my food,

Whipped and tormented. (I, ii, 54-56)

Romeo's fixation is a harmless one that deserves the castigation of ridicule. Judged from the standpoint of reason, represented by Benvolio's sage counsels and Mercutio's mockery, his servitude to Rosaline is ludicrous, for he shows an absurd pertinacity in his unswerving devotion to some one who can feel nothing for him. Romeo's foolishness lies not so much in the traditional signs of love as in his obstinate persistance in a hopeless suit. However the first manifestations of reason combatting his folly have already appeared in Romeo himself, for he betrays certain irrepressible doubts about the true value of his emotions : «This love feel I that feel no love in this» (I, ii, 108) he ruefully admits. The very fact that he opens his heart to Benvolio shows that extravagance is receding, as Benvolio can be trusted to propose the usual cure for love that involves seeking new faces and different social 
relations that can be compared with the old ones and counteract their influence. Though Romeo starts by rejecting this sagacious advice out of hand as heresy to his religion of love, he does attend the ball, where the first glimpse of Juliet confirms the puerility of his calf-love.

The innocuous nature of Romeo's first attachment is stressed by the comparison established in the opening scenes of the play between his foolish ardour and a much more serious type of aberration : the feud opposing the house of Montague to that of Capulet. The causes of the vendetta are never evoked, they are lost in the mists of time. The feud has become quite irrational, more the product of physiological circumstances than anything else, such as the effect of the hot climate on temperaments dominated by an excess of choler. As Benvolio remarks somewhat fearfully : «Now these hot days is the mad blood stirring» (III, $\mathrm{i}, 4)$. The result is a constant state of pernicious irritation that finds periodic outlets in aggression. The most primitive instincts of masters and servants alike burst out into fits of berserk rage on the slightest provocation, unrestrainable by any counsel or act of discipline; The feud channels and directs the general state of fury at one particular object - the rival family. The blindness of their frenzy allows them to ignore the others as individuals or even as humans, they just think of them as a hostile mass of Montagues or Capulets that must be attacked and destroyed, and any means including treacherous blows are valid. Hence the frantic rage of Tybalt makes him prepared to violate the most sacred laws of hospitality and duelling.

The feud rages through the city like the hectic in the blood involving and killing guilty and innocent alike. It sets the tow on a course of mutual destruction that could mean the end of any normal life or government in Verona. The vendetta establishes in the city two hostile blocks that are mutually impenetrable and that constantly expand and incorporate into themselves hitherto neutral observers. Thus the Prince's allies, Mercutio and Paris, find themselves obliged to forsake their independence and to adopt the stance of the family with which they are most involved. These free rational spirits then find themselves overwhelmed by the contagious insanity of the feud and are sacrificed to it. The mad frenzy of the vendetta thus proliferates in the city like a cancerous growth sapping the forces of reason and discipline opposed to it. The stern justice of the magistrate, Prince Escalus, aided by the calm reasonableness of the peace-maker, Benvolio, and the efforts of the philosopher, Friar Laurence, endeavour in vain to contain the suicidal insanity of the feud. The women and the citizens also do their feeble best to restrain the murderous tendencies of the feuders. Faced with such universal disapproval it even seems possible at one point that pacification might be accepted, when the elderly leaders listen to the Prince's expostulations and are bound over to keep the peace. But this is a mere façade of rational behaviour, the most trivial incident quickly revives the infernal obsession of the vendetta once more, and Verona lies helpless, riven apart by the raving lunacy of the two warring factions.

The younger generation are particularly affected by the feud since it creates a claustrophobic, prison-like family background that sets up unnatural barriers 
between the junior members of the rival clans. Going to a ball becomes a perilous enterprise. This is all the more regrettable as the feuding situation secretes its own antidote in the shape of the curiosity of the young people about the enemy family. Inevitably perhaps Romeo is already attracted to a beautiful young Capulet, Rosaline. While the final remedy to the situation lies at hand in that Romeo and Juliet are the only son and the only daughter respectively of their two families. Lord Capulet's praise of Romeo is a glimmer of reason in the general irrationality of the vendetta that gives a momentary hope that love and union may heal the breach. This hope is given credence by Friar Laurence's prompt acceptance of the marriage of Romeo and Juliet as a prelude to reconciliation. But though Lord Capulet has a reasonable, even a noble idea of hospitality and protects Romeo from Tybalt's intended aggression, the distorted values of the feud will thwart the reasonable way of marriage. Fear of her kinsmen's violence will prevent any open demand for Juliet's hand and make agreement depend on time for Friar Laurence to undertake the necessary process of persuasion, and that essential lapse of time is never vouchsafed.

A further baleful consequence of the feud is the unacceptable tyranny of the past over the present. The vendetta paralyzes any hope of change and reduces the families to a catatonic state, rendering them incapable of accepting new ideas or attempting any new approaches. The dead hand of the past is represented by the menacing presence of Juliet's ancestors in the family vault. The disordered nature of the feud they have imposed on their descendants insinuates itself into Juliet's imagings as she thinks of herself madly playing with her forefathers' joints, dashing out her desperate brains with some great kinsman's bone. The past history of the vendetta has usurped the history of the community as entity and imposed its own perverse laws and values. Loyalty to the clan represents the prime value and dictates reactions of illogical suspicion and hostility to the others. Tybalt on seeing Romeo at the ball jumps to the conclusion that the Montague has come to scom at their solemnity, while Paris later on supposes immediately that Romeo has come to do some villainous shame to the dead bodies in the Capulet tomb. This habitual recourse to irrationality that is the hallmark of the feud and its collective hysteria will above all be the cause of Romeo's tragic yielding to the madness of revenging Mercutio's death, just as he will respond to Paris' misconceptions by his own distraction, and slay the young Count for provoking him and barring his way to Juliet.

The aberrations of the feud destroy any chance of a peaceful fulfilment of the true love of Romeo and Juliet. Judged from the point of view of the vendetta it is absurd to think their union could ever be accepted, and even considered by the ordinary standards of attachment their passion seems pure folly. In the balcony scene Juliet has a momentary qualm and contemplates their relationship through reason's eyes for an instant : «It is too rash, too unadvis'd, too sudden» (II, ii, 118), she is obliged to say. Reasonable love needs time to develop, and to be lasting it must be moderate, whereas their passion strikes like lightning. But the intensity and reciprocity of their love redeem it from any charge of foolishness. Their passion is 
justified by its depth and purity, the shallow artificiality of Romeo's first love and the bawdy insinuations of Mercutio fade into insignificance compared with the boundless emotion the lovers now feel. The eminent judiciousness of their mutual devotion is moreover proved by their complete repudiation of the feud and their exaltation of union and harmony, not only with each other, but also with all the smoothly interlocking parts of the macrocosm. Their love like Juliet's starry eyes :

Would through the airy region stream so bright

That birds would sing and think it were not night (II, ii, 21-2)

Indeed we may say that their passion is reason incarnate for it leads to serenity and fulfilment as a natural and normal course. Romeo is himself again and Juliet dreams with rapture of «true love acted simple modesty» (III, ii, 16).

The audience who formerly laughed at Romeo's infatuation have, as they watch, started to identify themselves with the cause of his true love for Juliet. The story of the feud and Romeo's first courtship serve in reality to manipulate the spectators into a process of conversion to the higher ideals of real love, represented by Juliet and Romeo's devotion to her. Now the public will judge adversely those who continue to blaspheme against love and who (unwittingly it is true) contribute to the destruction of something so fine and precious. Unilluminated by the truth of the matter, the characters who are hostile to love begin to exhibit new and unpleasant traits. Instead of being advocates of reason, which is how they still see themselves, they now stand revealed as purveyors of madness. Mercutio is a case in point. Mercutio had opposed to Romeo's fervour the reasonableness of his cynical judgement of love and his cool detachment from wild passion but now he betrays his uncontrollable temper and his adherence to the absurd precepts of a perverse code of honour, denigrating Romeo's noble efforts at peace-making as «calm, dishonourable, vile submission» (III, $\mathrm{i}, 72$ ). Spoiling for a fight with Tybalt he provokes a motiveless combat and turns the course of events into a tragic channel. Lord Capulet had manifested in his first interview with Count Paris an extremely sagacious attitude to Juliet's happiness. He now shows himself to be animated by a lunatic desire to impose his will at all costs on his daughter and any evidence of resistance just serves to exacerbate his frenzied despotism. His crushing of Tybalt's murderous intentions at the ball had seemed generous, but now his violence is applied to Juliet with such disproportionate vehemence that we can see the blind tyrannical intransigeance lying behind his apparent geniality. The crossing of his will sends him into a senseless fury and even Lady Capulet who approves of his actions, is aghast at the frantic haste with which he advances the date of the forced match.

In the same way the female characters who deny love, unmask hidden aspects of their personality that cast doubt on their morality and on the capacity of their judgement. Lady Capulet who had formerly tried to restrain her husband's 
ferocity now presumes that Juliet's supposed grief-over Tybalt's death will be calmed by her proposal to have Romeo secretly poisoned in exile. The Nurse who had seemed completely won over to Romeo's cause, sees nothing wrong in applying the same terms of praise to Paris and encouraging Juliet to commit bigamy. Madness is now encamped in the hearts of those who had seemed to defend the cause of reason and they are responsible for driving the lovers to despair and self-destruction.

As the tragic concatenation of events unfolds, so the suffering of the lovers proclaims the incoherence of the occulte powers reigning over their universe, for instead of protecting innocent, virtuous lovers, they make of them Fortune's fools. The friar sees evil in the world as provoked by the warring elements in Man : grace opposed to rude will. But the tragic incidents of the play also point to a certain giddiness in the higher powers as the cause of disaster. Logically the heavens should smile on the holy act of matrimony, instead of which they frustrate every human effort to preserve the couple from calamity. They present the lovers with sweet baits but on fearful hooks indeed, turning all well-meant acts to catastrophe. Juliet seems to recognize the disordered nature of the intelligence ruling over their destiny in her apostrophe to Fortune :

O Fortune, Fortune! All men call thee fickle ;

If thou art fickle, what dost thou with him

That is renown'd for faith? Be fickle, Fortune,

For then I hope thou wilt not keep him long,

But send him back. (III, v, 60-64)

A touch of schizophrenia may be detected in the workings of Fate. At the beginning of Act V Romeo is first treated to a joyful and basically correct dream of Juliet alive and reviving him from the death of his exile, but then Balthasar is allowed to reach him with the false news of her demise, while Friar John is malevolently detained. The split personality of the occult powers was in fact indicated early on in the play in Romeo's musings before he entered the ball room. First he had the intimation of some consequence bitter to himself hanging in the stars, but then he felt encouraged to trust in a benevolent Providence : «he that hath the steerage of my course Direct my sail $\gg(1, \mathrm{iv}, 112-3)$ he exclaims, not dreaming that the reward of his confidence will be final shipwreck. It is perhaps not surprising that at the point of death, the lovers do not evoke any idea of their souls meeting in heaven, as those in the source stories $\mathrm{do}^{2}$. They are content to rest in peace together «shaking the yoke of inauspicious stars from this world-wearied flesh $>(V, \mathrm{iii}, 111-12)$ as Romeo puts it, their only secure trust being in each other.

The wantonly tragic outcome of the love affair imposes then a new idea of reason and madness. Reason being the faculty connected with order, sensible conduct and practicality, is associated in the play with domestic and social order and 
the maintenance of established custom. The prime example of the folly implicit in such reason is the arranged marriage of Juliet and Count Paris. According to the rational view of things taken by Juliet's parents, this match is a perfect one, since the two young people are equally handsome and accomplished and the union will bring wealth and social advancement to their daughter and themselves. But reason is materialistic and obtuse to any other considerations. It encourages Lord and Lady Capulet to dismiss Juliet's protests as mere caprice, for her resistance is founded on claims to personal preferences and spiritual affinities to which rationality remains profoundly indifferent. The strict application of reason leads them to the brutal treatment of Juliet as an object Lord Capulet wants to give to his friend. Reason is so dehumanizing, so limiting in its understanding of the heart, that the folly of persisting with their intentions quite escapes them. The tragic irony of the play stresses then the fact that reason in this domaine is catastrophically at a loss. It is madness for Lord and Lady Capulet to think they can control Juliet's emotions by reason, when they cannot even impose rational restraint on such simple souls as their servants, let alone on themselves. The unalloyed use of reason in short becomes so stultifying that they commit the folly of attaching more importance to the trivial arrangements of the wedding feast than to the pitiful pleas of their only child, and in the name of reason they drive her to despair and suicide, thus destroying what is most precious to them on earth.

The same type of stricture can be applied to the main figure representing reason and moderation in the play, that is Friar Laurence. Reason is based on logic and is thus alien to things of a different nature. «Madmen have no ears», says the Friar, «Wise men have no eyes», retorts Romeo (III, iii, 62-3). Even wise men cannot speak of what they cannot feel, and reason is particularly blunting to the Friar's emotions through the oversystematic use he makes of philosophy to moderate the perturbations of his charges. The rational arguments of philosophy he evokes tend to eliminate intensity from his vision of things. «Nature's tears are reason's merriment $\gg$ he declares (IV, v, 83). The result of this rationality is, in exceptional circumstances, the paralysis of his imagination, so that he fails to invent any bold or original solution to the young couple's problems, such as urging Juliet to elope with Romeo, or applying to Lord Montague for help. The Friar's rational attitude encourages him to work by more modest means of expedients and secret stratagems that avoid upheavals and open clashes with the status quo. But the Friar's reason then becomes so reasonable that it refuses to go beyond a certain point of audacity or risk, and his prudence finally leads to a fatal act of cowardice when he flees from the grave-yard to avoid arrest and thus allows Juliet to join Romeo in death.

Our conclusion then on reason in this tragedy is that it shows itself to be inadequate, associated with the handicaps of old age and loss of vitality. What Juliet says of the nurse can apply to reason also, it too is «unwieldy, slow, heavy, and pale as lead s, (II, v, 17). It is a destructive force in the play, one that wreaks havoc, a major cause in fact of the tragedy.

On the other hand such seeming forms of irrationality as total passion and 
the sacrifice of the young lovers' lives reveal themselves to be the way to a higher form of reason that Leone Ebreo in his Dialoghi d'Amore calls «extraordinary reason». Ebreo explains that :

The purpose of extraordinary reason is the attainment of the possession of the beloved and it takes no care for the safeguarding of our own interests, but prefers before them possession of the beloved, even as the best is to be preferred before the good ${ }^{3}$.

For Ebreo excess in love is not to be condemned as madness, but is to be praised for heightening virtue ${ }^{4}$. The apparent folly of total passion that throws off all restraints becomes liberating in a context where social forms have degenerated, since it allows a successful rebellion against an order that has become perverse. The lovers' suicide presents itself then as the logical consequences of their adherence to higher absolute values, those in particular of fidelity and loyalty. It is motivated by a mystical belief in the indestructible bond of love, such imperishable love being a supreme manifestation of reason. As Ebreo puts it :

Love ordained by reason sheds forth a great sweetness not only to carnal appetite but to the immaterial mind through inextinguishable affection ${ }^{5}$.

The reasonableness of their passion can also be demonstrated by Platonic doctrine. Somewhat in the manner of Plato's androgyne ${ }^{6}$, the two young people recognise each other instantly as the soul-mate who completes their being. It is not folly on Romeo's part to writhe on the floor in anguish at the thought of his banishment, since his pain corresponds to the wrenching apart of his new-found entity, the two of them having been incorporated into one for ever. Such mutual completion through love is further underlined by the Platonic vision of cosmic love manifesting itself through human love and working against the forces of disorder. As Marsilio Ficino says in his commentary on Plato's Symposium:

Love is a perpetual knot and binder of the world, the immovable support of its parts and the firm foundation of the whole creation?

This unifying function of love is moreover ratified in the case of Romeo and Juliet by the marriage bond. The rehabilitation of marriage by Reformation thinkers 
would encourage Shakespeare to see in holy matrimony the supreme expression of love. The epithalamium pronounced by Juliet is similar in feeling to Spenser's poem ${ }^{8}$ and shows married love to be in harmony with the rational principles underlying the structures of the cosmos. This constitutes the basis of the cosmic imagery used by the two lovers : Juliet is the centre of Romeo's dull earth, the sun that illuminates his world, and rather than fall back into fragmentation and primeval chaos, they prefer to move forward together into death.

Their choice would appear to be a wise one, for death will not see the end of their attachment. Romeo looks forward to an eternity spent with Juliet in the grave, but the clay of their bodies has, so to speak, been transmuted into everlasting gold by the alchemy of passion. Shakespeare therefore replaces the marble tomb of his source $^{9}$ by twin golden statues bearing witness to the lovers' spiritual union that transcends Death and Time. Furthermore the Friar's last speech, far from being superfluous as is usually thought, stands as a vital contribution to the immortal nature of their love, because it lays down the basic elements of their story as it will be endlessly repeated to the farthest edge of time. «Philosophy cannot create aJ uliet but poetry can» as $\mathrm{H}$. Goddard remarks ${ }^{10}$. With the complicity of Art and Poetry their love escapes extinction and imposes the logic of its reasoning not only on the Montagues and Capulets who accept reconciliation now, but also on all future generations who will be moved by the story of the young couple's tragic fate.

The play is therefore a plea for a greater relativity in rational judgements that must allow for higher things and it denounces the madness of pedestrian rationalism that denies the extraordinary reason of love. Shakespeare's exaltation of the conjunctive and curative force of love is one that appeals very especially to modern audiences. The tepid approbation accorded to the tragedy by many critics and the laboured efforts of certain to persuade us that the two lovers are guilty and sinful ${ }^{11}$ cut right across our intimate conviction that the two young people are in the right. The story of Romeo and Juliet pleads for something we have never before felt to be so urgently needed : the acceptance of the reasonableness of love in an insane world of hate. 


\section{NOTES}

1 See the description of love melancholy given by Robert Burton in The Anatomy of Melancholy, vol. I, Tudor Publishing Co., New York, 1927, p. 721-65.

2 In Arthur Brooke's poem The Tragicall Historye of Romeus and Juliet, 1562, translated from Bandello, Juliet prays that: «Our parted spirits from light that we see here in place of endlesse light and blisse may ever live yfere», lines 2787-8.

3 Leono Ebreo (Judah Abravanel), The Philosophy of Love, (Dialoghi d'Amore), translated by F. Friedeberg-Seeley and Jean Barnes, Socino Press London, 1937, p. 63. The work published posthumously in Rome, 1535, was well-known and influential, quoted by such writers as Burton, Bacon, Bruno, Montaigne and Castiglione.

4 Ibid, p. 59.

5 Ibid, p. 64.

6 Hephaestus asks the reunited androgyne : «I am ready to melt and weld you together, so that, instead of two, you shall be one flesh; as long as you live you shall live a common life, and when you die, you shall suffer a common death, and be still one, not two, even in the next world. Would such a fate as this content you, and satisfy your longings ?» Plato, The Symposium, translated by Walter Hamilton, Penguin edition, 1951, p. 63-4.

7 Marsilio Ficino, Commentary on Plato's Symposium, ed. S.R. Jayne, Un. of Missouri Studies 19, 1944, p. 152.

8 A.R. Cirilio, «penser's Epithalamion : the Harmonious Universe of Love», S.EL. $1500-19008,1968$, p. 19-34. Gary McCown's interpretation of Juliet's speech is rather unsatisfactorily negative : «Runaway Eyes and Juliet's Epithalamium», Shakespeare Quarterly 27, 1976, p. 150-70.

9 Arthur Brooke's poem describes a stately tomb of marble on great pillars and decorated with epitaphs, lines 3014-6.

10 H. Goddard, The Meaning of Shakespeare, Un. of Chicago Press, 1951, p. 124.

11 See especially James H. Seward, Tragic Vision and Romeo and Juliet, Consortium Press, Washington, 1973. 